\title{
Childhood Rectal Carcinoma
}

National Cancer Institute

\section{Source}

National Cancer Institute. Childhood Rectal Carcinoma. NCI Thesaurus. Code C118823.

A rare carcinoma of the rectum that occurs during childhood. 